\title{
PATRICK HAMILTON'S CRAVEN HOUSE: PARODYING THE EDWARDIAN WELTANSCHAUUNG
}

\author{
Roy Janoch, University of Zaragoza \\ Email: rjanoch@unizar.es
}

Received: September 24, 2020

Accepted: November 21, 2020

\begin{abstract}
The following article is concerned with the depiction of the social decay of the Edwardian middle class in Patrick Hamilton's serio-comic inter-war novel Craven House (1926). It is argued that while Hamilton satirises their conservative Weltanschauung, he also associates it with their social downfall. Beginning with an analysis of Hamilton's own experience as a child of an Edwardian middle-class family, the article proceeds to examine the various facets of the Edwardian worldview that Hamilton satirises. It is concluded that the author's critique of the Edwardian worldview acts at its core as nothing more than a metaphor for their social disintegration.
\end{abstract}

Keywords: Patrick Hamilton, Craven House, Edwardians, Weltanschauung, class, boarding house, social decline.

Resumen: El siguiente artículo trata sobre la representación del declive social de la clase media eduardiana en Craven House (1926), una novela serio-cómica de entreguerras de Patrick Hamilton. En este artículo se defiende que mientras Hamilton satiriza su conservativa Weltanschauung, también la asocia con su decadencia social. Comenzando con un análisis de las experiencias de Hamilton durante su infancia en una familia eduardiana de clase social media, el artículo prosigue examinando las diversas facetas de la visión del mundo eduardiano que Hamilton satiriza. Se concluye que la crítica que el autor hace sobre la visión eduardiana del mundo no es más que una metáfora de su propia desintegración social.

Palabras Claves: Patrick Hamilton, Craven House, eduardianos, Weltanschauung, clase, casa de huéspedes, declive social.

The British upper-middle-class novelist and playwright (Anthony) Patrick (Walther) Hamilton (1904-1962) is generally referred to as an author particularly portraying and 
parodying the British working poor of the interbellum (Thompson 2013). However, after reading all of his novels in detail, I came to realise that this is a romanticised myth. The fictional works of Hamilton, who acquired a world-wide reputation as an acclaimed writer sometime in the mid-1920s, can certainly be said to be peopled by those that since the onset of the Great War had become disenfanchised and ostracised. Yet contrary to the popular belief, this 'defeated' walk of life does not constitute the lower orders, but the class that Hamilton himself knew best, the (lower)-upper-middle class of southern England. To put it differently, the social stratum Hamilton mostly wrote about is that of his own socio-cultural millieu, a matter that was not least fostered by his own experience of growing up in this environment.

Born into an upper-middle-class household at the turn of the twentieth century, Patrick Hamilton was from a very early age on confronted with the class consciousness and the social pretensions characteristic of the Victorian and Edwardian middle classes. His father, Bernard Hamilton, a deeply tragi-comic character, frequently boasted about his genealogical table and even pretended to be the rightful heir to the throne of Scotland. Yet most of these claims were obviously nothing else than figments of the imagination of a narcissistic swaggerer. He was also an ardent patriot and militarist, taking pride in the heroic deeds of a certain Colonel Edward Wildman, "a hero at the Battle of Watterloo" and one of his genuine aristocratic ancestors. ${ }^{1}$ What is more, he was a Mussolini devotee and one of the founding fathers of the ultra-right-wing melting-pot known as British Middle Class Union - later as National Citizens Union and despised the lower classes and all those that did not fit into his preconceived worldview. He also thought of himself to be a great writer although the few books (novels) he penned - soppy romances and some hotchpotch of religion and spirituality -, were mediocre at best.

The snobbishness and pretentiousness was, all the same, not only restricted to Hamilton senior. On the contrary, Patrick's mother, Ellen Adele Hamilton (commonly known as Nellie), was at least as pretensious and snobbish as her husband. She treated her domestics with haughtiness; never hesitated to dismiss a servant or nursemaid at the smallest sign of misconduct. On one occasion, she dismissed the children's favourite nurse on the grounds that she had come late from a social event; surrounded herself only with members of the upper-middle and upper classes; attempted to breed her children as members of the high society; and generally divided people into gentlefolks, commons - a term wryly used by Hamilton in some of his works -, lower orders and occasionally borderline cases.

All these pretentious manners and behaviour in the Hamilton family did not go unnoticed by the children, particularly by Patrick who from a very early age on showed a remarkable intellectual curiosity, distinct observation skills, a strong sensitivity towards his social environment and a gift for reproducing and imitating language. The result of this talent was that the young Patrick did not only compose all kind of comical tales about fictitious middleclass families, but also imitated his parents' behaviour, particularly that of his father. As I will later illustrate, Master Wildman, the partly autobiographical child-narrator in Craven

1 This information is taken from the article "Genealogy by Gaslight: The family tree of novelist Patrick Hamilton". The article is freely available on Historyeye, a professional Dublin-based genealogy service. It does neither feature the date of publishing nor any pages. 
House, who, as the name bespeaks, is named after the before-mentioned Colonel Edward Wildman, reflects some of Patrick's early dealings with this issue.

Growing up during the first decades of the twentieth century in a semi-aristocratic upper-middle-class household, Hamilton was also an eyewitness to the social decline of his own class that was brought about by the First World War and the social transformation that came along with it. He experienced the gradual downward mobility of the Edwardians and their poor attempt to brace themselves against it by hanging on to their old, conservative world-view by refusing to connect with the modern world first-hand. And this is also what Craven House (1926), the novel to be discussed in the following lines, is about. It is a deeply schematic book in which the inner stagnation and decay of the Edwardians is registered in their Weltanschuung. And although the social conventions and mindsets evoked parallel those of Hamilton's own parental (bourgeois) home, the novel constitutes a phenomenological, but fully-realised fictional, work based on his war and immediate post-war experiences and observations during sojourns in boarding houses in and around London.

For the Hamilton family in general and the young Patrick in particular, the end of the period that later, from the 1920s on, became known as the "Lost Golden Age" (Priestley 2000: 55) was ushered in by the onset of the First World War. In his memoirs, Patrick: $A$ Tragedy, Hamilton's brother, Bruce, writes that the first time they (Patrick and he himself) became aware of the end of the 'romantic' Edwardian period and therefore of their blissful childhood was ironically during a cricket game, one of Patrick's favourite sports during his childhood:

At a little after three o'clock, martial music was heard. [Soldiers] marched right on to the playing area, disregarding the players [...]. The cricketers stood around for a minute or two, looking foolish; then they straggled off the field and the umpires pulled up the stumps. That was how the war first came to Patrick and myself. [...] To Patrick and me this happening [...] became and remained the ungracious symbol of the end of an age (1969: 73-74).

From that moment on, the idyllic life that the Hamiltons and other middle-class families enjoyed during the 'secure and stable' Edwardian period was to end, and this matter is also reflected in his novels, which, as already indicated above, contrary to the popular assertion, do not predominantly feature working-class characters, but those of his own milieu, the bourgeoisie. It should be noted at this point that despite also going through a rough patch during and after the war, due to a large inheritance they came into at the turn of the century the Hamiltons themselves were not as affected by the social change as other middle-class families.

Craven House, Hamilton's second novel and the only one of his early period books to remain in print, is a serio-comic novel that, as already stated above, is based on the author's own early experiences in boarding houses, particularly in Kew House (15 Kew Gardens Road), a central London lodging house where Hamilton stayed with his mother temporarily in 1925 as "paying guest[s]" (B. Hamilton 1969: 235) - an expression that is also used for the tenants of Craven House. This London tale is concerned with the disenfranchised Edwardian middle-class society that, having lost its historical position of stability, security and superiority, was faced with impoverishment, social exclusion and the public humiliation of having to reside in shared accommodation. 
Within this framework, the novel narrates the story of a young boy called Henry Wildman - throughout the novel referred to as Master Wildman - and of Elsie Nixon, a young girl who is eventually to become his girlfriend. Both children meet at the eponymous lodging house and grow up together among a collection of grotesque figures maturing mentally and morally according to the trajectory of the traditional protagonists of a Bildungsroman. This matter is significant in the sense that, as we will later see, these two characters represent a generation that initiates the end of the traditional Edwardian (formerly Victorian) middleclass way of life.

As already implied, the fictional world of Craven House features a variety of paying guests. Of all these lodgers, the best drawn characters are, in my opinion, Mr Spicer, a tea merchant who has a penchant for frequenting bars and brothels, and Elsie Nixon, who is a young fatherless girl subjected to a disciplinary regime of obedience, humiliation and violence by her puritanical mother. Both of these expressive characters are based on real acquaintances of Hamilton. As regards to Mr Spicer, he constitutes a caricature of a certain Mr Doughty, a barrel of laughs who, together with his wife, hosted the Hamiltons at Kew House. According to Hamilton's brother Bruce, it was the blend of creative ideas from Hamilton's own mental repertoire and the foibles and moral vagaries of Mr Doughty that led to the creation of Mr Spicer (B. Hamilton 1969: 250), in my view, one of the most comical monsters in the history of British literature. The gentle and reserved Elsie is based on an unhappy child under the thumb of a horrible mother, observed by Hamilton years before during a stay in another boarding house. Master Wildman, the protagonist, who intermittently turns into the child-narrator, is slightly autobiographical. Some of the chapters of his childhood and early adulthood are certainly grounded on episodes of the author's own early life: his experiences at primary school, his bedtime stories with Elsie, his job as a typographer or the beginnings of his writing career.

As Nigel Jones (Hamilton's biographer) correctly describes in the "Introduction" to Craven House, the dominant note of Patrick Hamilton's oeuvre is, "despite all the laughter in the dark, [that] of ultimate despair" (2008: xi). Yet, as he goes on to state, "in Craven House that bleak note has not yet been struck" (2008: xii). This matter resulted from the fact that the time in which Hamilton composed this early London tale - the first six months of 1926 - was, as Hamilton registered in his autobiographical notes, Memoirs of a Heavy Drinking Man (1956) or in some of his letters to his brother, one of the happiest and most untroubled in his life. According to Bruce, during that period "Patrick would come down from his room and read to [the family] his morning's work - the only time in his life he ever did anything like this" (1969: 248). His mother's reactions were "Beautiful! [...] Exquisite! [or] Perfect!" followed by "laughter and tears" (1969: 248).

As suggested above, the novel is concerned with the gradual social decline of the author's own social stratum, the so-called Edwardian middle class, that is, the class that belonged to the political establishment under Edward VII. At the same time, Hamilton's satirical engagement with the social decay of his own class is not so much manifested in the loss of its socio-economic position, which is undoubtedly there as well, but rather, as I argue, in its tenacious adherence to the assumption of possessing a God-given superiority. In other words, the point that I wish to make at this stage is that at the same time as Hamilton satirises the Weltanschaunng of this class, he associates it with their social downfall. 
In order to simultaneously portray and parody the social decay of his own class, Hamilton carried out a variety of narratological experiments ranging from the use of free indirect discourse (FID) to that of dialogical exchanges. The novel, which is formally separated into three books, is orchestrated by an extra-diegetic, third-person narrator who constantly penetrates the individual consciousnesses of the characters in order to endow each of them with his or her own social voice as well as to create social interaction and emphasises those mental features of the class the characters represent that make them look the most ridiculous. Aside from that, occasionally, he projects himself (emphatically by merging his voice with one or more of the characters) into the diegesis to heighten the effect of certain viewpoints. As this type of narrative practices refracts the authorial voice, the text evokes although in somewhat neutered form -, some of the notions of carnivalesque and dialogism that Bakhtin explores in his famous book Problems of Dostoyevsky's Poetics (1999). To exemplify this matter, when the narrator merges his voice with one or more characters, he either satirically or ironically imitates their mindsets by the use of fable or allegory or he enters into absurd dialogues with other characters to accentuate the objectionable aspects of their discourse.

Although Craven House takes place in the period between shortly before the First World War and the mid-1920s, the residents of the boarding house, whom Mrs Hatt, the landlady, calls a "Sort of paying guests" (Hamilton 2008: 5, emphasis in the original), seem to be, as Jones encapsulates it, "marooned in a Victorian time-warp, still clinging on to the certainties of the past century" (2008: xiii). It is, as Nigel Jones goes on to state, "still a safely upstairs-downstairs world" (2008: xiii) where everybody, including those of the basement class, that is, the servants below-stairs, knows their place.

However, the boarding house also represents a claustrophobic place, one in which its denizens are disgracefully forced to live together in cramped conditions owing to a scarcity of economic means. Most likely inspired by Vane Sutton's play Outward Bound (1924), this setting evokes the 'torture' chambers of plays such as Jean Paul Sartre's No Exit (1944) or Anton Chekhov's Uncle Vanya (1897), Tree Sisters (1901) and The Cherry Orchard (1904). Moreover, it is, as Jones implies, not difficult for Hamilton to convince the readers that "Sartre's dictum 'Hell is other people" prevails beneath the fooling Gemütlichkeit of the lodging home (2008: xi), an adage that applies to almost all of the boarding house's residents, all of whom are at the same time victims and victimisers. As in Sartre's depiction of inferno, it seems as if they have been placed together to make each other's lives miserable.

The novel makes a leisurely start providing a depiction of the eponymous lodging house, its location and its semi-permanent inhabitants. Craven House is an old mansion used as a boarding house and situated in "Keymer Gardens" (Hamilton 2008: 1), a neighborhood in south-central London at the beginning of twentieth century. Like the Fauconberg Hotel of Hamilton's first novel, Monday Morning (1925), which later reappears in the author's poignant (political and psychological) pre-Second-World-War thriller Hangover Square: A Tale of Darkest Earl's Court (1941), the boarding home functions metaphorically as a sign of "a certain post-war deracination among a stratum of [previously] moneyed people, bereft of their erstwhile servants and households" (McKenna 1991: 174).

This supposedly genteel establishment is owned by Mrs Hatt, an elderly lady, who, as we soon get to know, purchased the house "some five months" (Hamilton 2008: 5) before 
the onset of the story in 1911. The decision to acquire Craven House was taken by Mrs Hatt together with her two life-long companions and best friends, Mr and Mrs Spicer, who, as we also learn, promised Mrs Hatt to "help [her] with the expenses" (2008: 5) since the house "would have been too large both for her intentions and her personal funds" (2008: 5). Craven House is, all the same, still too large for Mrs Hatt's budget, and so, after living there only for a few months, she resolves to rent out rooms. Following this decision, four people move in: a certain widowed Mrs Nixon with her young daughter Elsie and a Boerwar veteran called Major Wildman and his son Master Wildman. Apart from this, we learn that Mrs Hatt employs two domestic servants: Audrey Custard, a submissive young housemaid whose only friend in the household is Mac, an aggressive, talking parrot, and Edith Potter, a cook with a grotesque personality whose presence could be, as the lodging house's inhabitants declare, only tolerated by considering her a "'Dickens character"' (2008: 30). As is already indicated here, it is not only the would-be gentility that is lampooned, but also the down-stairs class and its subculture, albeit with a warmer sentimentality.

As already implied before, Book One serves in large part as an introduction to the various characters of Craven House. And although nothing really happens, and, at first sight the figures seem to represent an honourable society, it becomes very soon evident that nothing is at it seems, that the entire story is a parody of the Edwardian (formerly Victorian) worldview, that beneath the surface of genteel correctitude and Edwardian morality lurks the depth of human depravity: "snobbery, insensitivity, prudery, hidden sexuality, cowardice, moral flaccidity, prejudice, complacence, [and so forth]" (Widdowson 1978: 121). In other words, the middle-class way of life the characters play out in Craven House evokes the social pretensions and the double standard of morality that were characteristic of Hamilton's class. At the same time, it is owing to Hamilton's power of storytelling that this London novel causes amusement rather than discomfort.

In George Orwell's sociological examination The Road to Wigan Pier (1937), he called this stratum the "lower-upper-middle class" (1958: 154) as its representatives were, as he argued, mainly low-rank (military) officers, civil servants, professionals, small-scale entrepreneurs, etc. Orwell explained that in the late Edwardian period, this walk of life "still felt [economically] sure of itself" (1958: 154), but then, during and after the Great War, when their situation commenced to aggravate, they refused to accept their fate and just attempted to "keep [...] up appearances" (1958: 156).

So what are the social pretensions that Craven House's inhabitants play out? Prima facie, the characters residing in the lodging house appear to be part of the elite of society. They convey the impression of being well-educated and well-mannered and to be living a care-free life except maybe for being enduringly confronted with the "acute and painful [...] Long Evening Problem" (Hamilton 2008: 5). Aside from that, they purport to be on friendly terms with one another and to live according to high moral standards. They eat and spend the evenings together whilst talking about bygone days, 'philosophising' and listening to the landlady reading out from a volume of Kipling's poetry or playing Chopin's mazurkas and polonaises on the piano. And 'as is right and proper for this social class', they also read the Bible and never miss out on any Sunday church service.

However, as already indicated above, slowly but surely, it becomes apparent that what resides beneath the surface of this 'genteel propriety' is nothing else but debauchery and 
moral rot. To put it another way, nothing is as it appears to be: the figures do not have the economic position they claim to have - they are more Lumpen than bourgeois, they do not take to one another as they attempt to make others believe, and finally, their faith ethics and their belief in God, King and Country which they heavily rely upon, are nothing other than a means to repudiate their social fall and to justify all kinds of immoral and antisocial behaviour.

An early example of the hypocritical nature of this 'noble society' is, for instance, manifested in the Sunday walks of Mr Spicer. On first sight, he has been happily married for over twenty years and is a professing Christian, that is, a true believer. However, we soon learn that under the pretext of going for walks, he every Sunday engages in pubcrawls and seeks out street women. Moreover, in the course of the story, we get to know that his pro-British imperial mentality consists of drinking, being lustful and fantasising about holding power. And when he resolves to go to war, we learn that even the political reasons for enrolling in the army are spurious, "nothing whatsoever of any nature to [him]" (Hamilton 2008: 93).

Noteworthy at this stage is that, in spite of Mr Spicer's prurience, the relationship between him and his wife and Mrs Hatt, with whom they form a peculiar triangle, is ironically loveless and sexless. The two women are figured as prudes, as inimical to female sexuality, - they constantly mock the new (sexual) self-liberation of women -, and Mr Spicer is projected as a shamefaced man who at night - when going to bed with his wife -, uses his nightgown "as sort of male burqa to protect his modesty" (Self 2016: x). At the same time, the combination of Mr Spicer's extra-marital indulgence and the two women's emotional frigidity exemplifies the bizarre and hypocritical nature of the sexual ethics that the Victorian ruling class preached. For, as Linda Gordon writes, the Victorian elite established a system of values that made procreation "the only worthy purpose of sexual activity" (2002: 9).

A more chilling facet of the pretentious nature of this class is evinced by its religiously motivated denialism and practices. For instance, it is from the outset of the story clear that the orthodoxy the inhabitants of Craven House attempt to project is false. Collectively, as exemplified above, their alleged belief in God serves them primarily as a means to feel part of the ruling caste and accordingly to mentally repress their own social exclusion and downward mobility. Individually, they additionally use faith (unconditionally) as a means to cope with their own blighted lives, to construct their own little (fantasy) world, very much along the lines of Pippi Longstocking's motto, "I create the world how I want it to be". A wonderfully portrayed example of the characters using faith in order to shun any reality whatsoever are Mrs Spicer's stock phrases (yes or no) addressed to the universe at the end of almost every conversation. These projections of her dogmatic denial of reality become most hilarious when set against her husband's 'clandestine' relationships with streetwalkers:

Mrs Spicer, emptying the pockets of Mr Spicer's coats preparatory to dispatching them to the cleaners, produced a letter addressed to Mr Spicer in what she afterwards summed up to herself as a Feminine Hand. 'Hullo,' said Mrs Spicer. 'What is this?' 'What dear?' said Mr Spicer, and came across the room to her. Mrs Spicer gave 'Yes' to the universe, and handed it over. (Hamilton 2008: 73) 
Though this lampoon on Mrs Spicer's quick readiness to hand over the letter is made to evoke great roars of laughter in the audience, it also underlines the desperate attempt of the Edwardians to keep their collapsing world intact by sticking to the old Victorian dogma that "religion was the only way to explain the world" (Evans 2011: 2).

At the same time as the novel projects characters as detached from reality because of their religio-culturally determined world-view, "it also creates a sense of genuine threat in the domestic and political violences it depicts" (Hallam 2011: 134). In this sense, the portrayal of the murderous Mrs Nixon and the sadistic upbringing to which she subjugates her two children, Jock - a castor-oil-wielding Fascist thug -, and Elsie - the female heroine of the story -, is unparalleled in the history of British serio-comic fiction.

For Mrs Nixon, religion is not so much a matter of faith or ostrichism, but a means to justify psychic and physical torture. Her cruel and sadistic nature is already symbolically evinced by her surname and rather dubious past. As her family name, Nixon, bespeaks, she impersonates a Nixie, a deadly mermaid that is notorious for appearing in human shape - always dressed in a skirt with a wet, dripping hem, bewitching and then killing men by dragging them down to the bottom of the sea, lake or river (Heine 2017: 12-14). These characteristics are also true of Mrs Nixon. Within the span of five years she became "unmarried (by death) twice" (Hamilton 2008: 22) - her last husband drunk himself to death in a nursing home -, and she always wears a red petticoat with a "malicious[ly] flicking [hem]" (2008: 54).

The religiously-motivated violence that Mrs Nixon then exerts to educate her two children is primarily reflected in the rearing of her daughter. Elsie is presented as a child "victim of Bringing Up" (2008: 21), as a victim of the authoritarian regime of her puritanical mother. Elsie is detested, humiliated and mercilessly tormented. As we are informed, she is subjected to a disciplinary system with various grades and shades of punishments - suitable to the various offences -, ranging from 'mild' sanctions like being "Sent Outside [or] to her Room, Locked in the Bathroom [or] Cupboard, Forbidden to Speak [or] Put in the Corner" (2008: 22) to more swingeing punishments such as "Cuffs and Boxes, [...], little Lessons, [and] Dressings Down" (2008: 22). And then there is, of course, the ultimate sanction, "the supreme penalty, [...] known as The Stick" (2008: 22).

The puritanical upbringing to which Mrs Nixon subjects her son has a different undertone. He has always been encouraged to be "a brave little man" (2008: 22) and recently packed off to a "smaller Scottish Public School - a hardy, open-air establishment where the boys eat salted porridge and run to bathe at half-past five in the morning" (2008: 22). However, as much as he might also be considered a victim of his mother's sadistic regime, he also constitutes the perpetrator. Not only does he share his mother's sadistic character, but he also represents a prototypical Fascist, the first of a series of (overtly) politicallycharged individuals appearing in Hamilton's fictional works.

Eventually, the initially seemingly safe world of this former rentier society is subverted. However, this subversion is not, as might be assumed, initiated by the class below-stairs, whose presence is mainly "felt through the muffled banging of oven doors and the 'smashing' of the gong summoning guests to meals" (Jones 2008: 119), but by their own offsprings, who are, in contrast to their elders, able as well as willing to connect with the modern world and accordingly take a stand against the repression of the past. 
The young generation's break with their own parents is preceded by the rebellion of the lower orders. In Book Two it is intimated that the years of the war were those "in which the Servant Problem first arose in stark uncompromised" (Hamilton 2008: 97). As already indicated, Craven House is not only concerned with the Edwardian middle class, but also with their servants downstairs, the class that is not supposed to contradict their masters and employers. And yet, one of the maids, Audrey, takes a stand and "answers back" (2008: 146); thereby, symbolically initiating the famous servant problem, the difficulty of "getting and controlling servants" (McQueen 2016: 17). At the same time, the novel suggests both, the changing Zeitgeist, which brought about a new female self-confidence, and the substandard, virtually slave-like working conditions as the chief cause of the housemaid's revolt.

Audrey's rebellion against her 'betters' then forms the signal for the overthrow of the entire social order on which the world of the boarding house is based: Audrey is dismissed - the servant shortage will remain a main issue of this class in Hamilton's later works. The vainglorious, pompous, double-faced and for a short time shell-shocked, sustained in the trench war in Flanders, Mr Spicer is at last confronted by his wife with his Sunday jaunts. The proprietress, Mrs Hatt, commences to grasp the excruciating pain of having to spend her life in the intimate company of those with whom she has no real relationship and very little to converse. And the now adolescent Elsie and Master Wildman, whose father has in the meantime died of a heart attack as a result of a psychological wound sustained in the Boer War, begin to rise up against their 'parents' ideology.

The emancipation of the young generation, which in the novel time-wise coincides with the obtainment of female suffrage, is initiated by Elsie revolting against the repression of the past. Encouraged by her beloved Master Wildman and Miss Cotterell, Hamilton's second femme fatale after Diane in Monday Morning (1925), a worldly, self-liberated young girl, who, considerably higher in the pecking order than the "Craven House class of persons" (Hamilton 2008: 116), represents the new middle class, Elsie at last confronts her oppressor. Having been refused to accompany Master Wildman and Miss Cotterell to a dance event and encountering her little green evening frock with the note "For the Dance" (2008: 180, emphasis in the original) slit in the wardrobe, Elsie buys herself a new dress, has her hair bobbed and returns home in order to face her tormentor. With all her suppressed, dark and unbearable memories suddenly coming back, she enters her tormentor's chamber and cathartically exacts vengeance on her mother. She "seizes [the stick] in both her Amazon's hands [and then] breaks [it] with a sound snap" (2008: 190) and says:

'It's no use your getting hysterical...' [...] 'I'm tall now,' [...] 'Taller than you. And I'm young. I'm young. And you're not going to make me old anymore.' [...] 'I'm not going to be made old any more!' [...] 'And that,' [...] 'will teach you - never to dare - to tear my green dress through again!' (2008: 190, emphasis in the original).

Elsie's triumph against her mother's tyrannical regime, especially against the backdrop of her statement "I'm young, and you're not going to make me old anymore" and hence against the conservative world-view of her class, bespeaks the young generation's break with their parents' values. Paradoxically, it is this generational conflict that prevents this class from total demise and secures some future hope through Master Wildman's and Elsie's mutual declaration of love. 
The denouement of Craven House, its final collapse, constitutes a piece of comic violence, an amalgam of high tragedy and delightful farce. In a last attempt to enforce her daughter's obedience, Mrs Nixon summons her son Jock, an overman-bred bully to the boarding house. One day, when Elsie refuses to eat Haggis, a Scottish dish of meat cooked in a sheep's stomach, Jock threatens to pour Castor oil down his sister's throat, a method that Mosley's goon squads employed to instill terror in political dissidents: "Like the Fascists give the Bolsheviks" (Hamilton 2008: 214). The great roars of laughter that a subsequent anecdote of Jock beating up a working-class agitator and then using this praxis on him provokes among the dinner attendees reveals that it is not only Jock who represents this misanthropic ideology, but the entire Craven House society. It becomes apparent here that although the novel had been written in 1926, Hamilton had already discerned the great potential for Fascistic evil emanating from this rentier class.

Following a subsequent fray between Master Wildman, standing up for Elsie, and Mrs Nixon's unpleasant, pseudo-Scottish offspring - he is actually only half-Scottish, over his Scottishness -, heated up by Mrs Nixon goading her son into thrashing Master Wildman and assaulting Mrs Hatt, the proprietrix finally loses control and releases her pent-up anger against her paying guests. A fight breaks out and mutton legs and plates are hurtled at one another. At the end, Mrs Hatt decides that she cannot stand to live among this 'honourable' society any longer and everybody is released, including Mrs Hatt's lifelong friends, the Spicers. Craven House closes, however, with the protagonist and Elsie reuniting at their former home weeks later and pledging love to each other. Against the backdrop of the endings of Hamilton's later works, this traditional mode of narrative closure might seem rather odd, but for Hamilton - writing at an early age -, the utter collapse of the Edwardians can still be prevented by youth and hope. Yet, this potential for some future optimism is only of very short time. Already a few years later, in The Siege of Pleasure (1932), the story of Jenny, a domestic servant turning into a streetwalker and thereby leaving her masters to face mortality, the fate of the Edwardians is to be sealed.

All in all, written in 1926, Hamilton's second fictional work can be said to be one of the earliest post-First-World-War novels that, instead of focusing on the portrayal of the well-to-do middle- or upper-classes and their trivial problems, directs its attention to a more disadvantaged social stratum, the Edwardian bourgeoisie. Their middle-class status owing to their social disenfranchisement and gradual fall into poverty since the late Edwardian era was only theoretical. At the same time, the central theme of the novel does not so much evolve around their economic decline, which, however, is there as well, but rather around their conservative Weltanschauung, more precisely, around its various facets. All the same, in the end, these aspects of their world-view are analogously to their economic situation exemplary for their social downfall. For, as Peter Widdowson writes, it "is what [these mores and mindsets] mean, rather than what they are, which interests [Hamilton], and they are already perceived and treated as symptomatic, as metaphors of social dissolution" (1978: 123). All things considered, it can be additionally stated that Hamilton's second novel is concerned with some major social changes British society underwent in the second decade of the twentieth century even if the upstairs residents of Craven House did not want to admit the factuality of these alterations. 


\section{REFERENCES}

Bakhtin, M. 1999. Problems of Dostoyevsky's Poetics. Theory and History of Literature, Volume 8. Ed. Caryl Emerson. Minneapolis: University of Minnesota Press.

Cheknov, A. 2002. Uncle Vanya. Anton Chekhov Plays. London: Penguin Books Ltd. 143-200.

Chekrov, A. 2002. Three Sisters. Anton Chekhov Plays. London: Penguin Books Ltd. 201-280.

Cheknov, A. 2002. The Cherry Orchard. Anton Chekhov Plays. London: Penguin Books Ltd. 281-347.

Dowdall, D. “Genealogy by Gaslight”. Historyeye. 24 July 2020. https://www.histo ryeye.ie/patrick-hamilton

Evans, R. 2011. “The Victorians: Religion and Science”. Gresham College. 26 August 2020. https://www.gresham.ac.uk/lectures-and-events/the-victorians-religion-and-science

Gordon, L. 2002. The Moral Property of Women: A History of Birth Control Politics in America. Urbana and Chicago: University of Illinois Press.

Hallam, M. 2011. Avant-Garde Realism: James Hanley, Patrick Hamilton and the Lost Years of the 1940s. University of Sussex. 14 May 2020. http://sro.sussex.ac.uk/id/eprint/7573/

Hamilton, B. 1969. Patrick: A Tragedy. Harry Ransom Research Centre, University of Austin (Texas). Manuscript.

Hamilton, P. 2008. Craven House. London: Black Spring Press.

Hamilton, P. 1972. Hangover Square. London: Penguin Books Ltd.

Hamilton, P. 1925. Monday Morning. London: Constable.

Hamilton, P. 1998. The Siege of Pleasure. Twenty Thousand Streets Under the Sky. London: Vintage.

Hamilton, P. 1958. Memoirs of a Heavy Drinking Man. Harry Ransom Research Centre, University of Austin (Texas). Manuscript.

HeIne, H. 2017. Elementargeister. Berlin: Hofenberg Sonderausgabe.

Jones, N. 2008. Through a Glass Darkly: The Life of Patrick Hamilton. London: Black Spring Press Ltd.

Jones, N. 2008. "Introduction.” Craven House. London: Black Spring Press. viii-xv.

McKenna, B. 1991. Gender Representation, Sexuality and Politics in the Writings of Patrick Hamilton. Wadham College Oxford. 20 July 2020. https://ora.ox.ac.uk/objects/ uuid:5d6338e3-f253-42d1-8cf6-4fd21d0514b5

McQueEn, A. 2016. A Class Apart: The Servant Question in British Fiction (1920-1950). University of Stirling. 18 August 2020. https://dspace.stir.ac.uk/handle/1893/24485\#.X2 taxi2B3PA 
Orwell, G. 1958. Road to Wigan Pier. New York: Harcourt, Brace and Company.

Priestley, J. 2000. The Edwardians. London: Penguin Books Ltd.

SARTRE, J. P. 2010. No Exit. New York: Samuel French, Inc.

SELF, W. 2016. "Introduction." Twenty Thousand Streets Under the Sky. London: Little, Brown Book Club. vii-xiv.

Thompson, L. 2013. “A gifted, whisky-loving chronicler of low-life.” The Telegraph. 12 July 2020. https://www.telegraph.co.uk/culture/books/10006994/Patrick-Hamilton-Agifted-whisky-loving-chronicler-of-low-life.html

VANE, S. 1924. Outward Bound. New York: Boni and Liveright.

Widdowson, P. 1978. "The Saloon Bar Society.” The 1930s: A Challenge to Orthodoxy. Ed. John Lucas. Hassock, Sussex: Harvester Press. 117-137. 